\title{
The complexities in system building strategies - The case of personalized cancer medicines in England
}

\author{
P. Kukk ${ }^{\text {a,b,* }}$, E.H.M. Moors ${ }^{\text {a }}$, M.P. Hekkert ${ }^{\mathrm{a}}$ \\ a Copernicus Institute of Sustainable Development, Innovation Studies, Utrecht University, Utrecht, The Netherlands \\ ${ }^{\mathrm{b}}$ Fraunhofer Institute for Systems and Innovation Research ISI, Karlsruhe, Germany
}

\section{A R T I C L E I N F O}

\section{Article history:}

Received 12 November 2014

Received in revised form 22 April 2015

Accepted 31 May 2015

Available online $\mathrm{xxxx}$

\section{Keywords:}

Personalized cancer medicine

Companion diagnostics

Technological innovation systems

System building strategies

Innovation ecosystems

\begin{abstract}
A B S T R A C T
Novel technologies often face difficulties in market uptake, especially when they differ significantly from already established technologies. In some cases, like personalized medicine, new technologies are composed of a number of parallel emerging technologies - in our case therapeutics and corresponding diagnostics - that are heavily co-dependent and cannot diffuse without each other. Therefore, actors in an innovation system need to engage themselves in complex system building strategies in order to create a more favorable environment for their emerging technologies. The bodies of literature on system building and innovation ecosystems have little overlap so far. In this article, we show how system building in a technological innovation system depends on different framework conditions in creating a market for personalized cancer therapeutics and corresponding companion diagnostics in England - such as technological complementarities, timing strategies and organizational complexity. Using this case we illustrate how notions from the literature on innovation ecosystems can complement the current system building literature.
\end{abstract}

(c) 2015 Elsevier Inc. All rights reserved.

\section{Introduction}

Entrepreneurs are commonly aspiring to be the first to introduce new innovations and technologies to the market (Adner and Kapoor, 2010). The emergence and diffusion of new technologies are complex and often very challenging processes since they frequently do not stand alone but depend on accompanying technologies (Adner, 2006). Also, they are frequently fundamentally different from an already existing technological structure (Musiolik et al., 2012). To bring these novel technologies successfully onto the market, the innovation system must be adapted to meet various conditions that often differ from the already established socio-technological regime (Geels, 2002). For this, the active engagement of innovative actors is needed in order to overcome macro-level obstacles in shaping the system according to the interest of new technologies (Farla et al., 2012).

\footnotetext{
* Corresponding author at: Fraunhofer ISI, Breslauer Str. 48, 76139 Karlsruhe, Germany. Tel.: + 497216809130 .

E-mail address: piret.kukk@isi.fraunhofer.de (P. Kukk).
}

In order for any novel technology to be a successful technological innovation, it needs to be taken up and adopted in a beneficial way by the market (Durst and Poutanen, 2013).

Our starting point is the technological innovation system (TIS) perspective that has become a popular concept in analyzing innovation processes around emerging technologies. It stems from the wider innovation system (IS) literature and deals with the analysis and improvement of the environment for the development and diffusion of emerging technologies (Markard et al., 2012). The TIS framework consists of different structural elements, such as actors or networks of actors, institutions and the interactions between them (Markard and Truffer, 2008a; Wieczorek and Hekkert, 2012). Besides structural components, the focus on systemic processes within TIS is a more recent addition to the concept (e.g. Hekkert et al., 2007; Suurs et al., 2009; van Alphen et al., 2010).

Since the TIS concept was originally developed to complement business literature on micro-level processes by adding a meso-level perspective, the focus in the analysis on structures and functions is mostly on the system level (Carlsson et al., 
2002; Jacobsson and Bergek, 2004; Musiolik et al., 2012). However, such focus might overlook the role of actor strategies and the importance of more agency-sensitive analysis in an innovation system (Truffer et al., 2012). Therefore, the role of agency in deliberate innovation system shaping has not received a lot of attention from the TIS community (Markard and Truffer, 2008a; Musiolik and Markard, 2011). Additionally the framework could benefit from better insights as to how actor strategies and resources impact overall system development (Farla et al., 2012).

The role of actor strategies is strongly conceptualized in system building literature that studies the deliberate creation or modification of different institutions and organizational structures (Musiolik et al., 2012). According to Hellsmark (2010), the system builder can be an individual actor or a group of actors that all dedicate resources to strengthen the structure and functions in a TIS, by going beyond narrow technology R\&D. The focus on actor level activities enables a better understanding of how different strategies, capabilities and resources of different actors (i.e. system builders) influence the overall system performance (Farla et al., 2012).

The TIS approach traditionally focuses on the interaction between different actors, organizations and institutions around one specific technology, but often does not explicitly consider technological interrelatedness. This relates to how the development and diffusion of a particular technology depends on other related complementary technologies (e.g. diagnostic technologies for personalized cancer therapeutics). As Adner (2006) phrased it - innovations rarely succeed in isolation but depend on other types of complementary innovations and technologies. Therefore, when talking about technological innovation systems as socio-technical systems, we also need to include and consider other relevant and often codependent, technologies in innovation systems to better understand the context of a TIS.

There are already some TIS studies on how different technologies affect each other (e.g. Sandén and Hillman, 2011; Wirth and Markard, 2011). These provide some evidence that besides competition, other types of interactions exist between technologies (i.e. co-dependency). These interactions can impact TIS development and the type of system building activities actors have to undertake to create a more favorable environment for their emerging technologies. However, these different technological complementarities have not been elaborated any further by the TIS community.

Technological co-dependency is heavily conceptualized in innovation ecosystem theory that originally emerges from management and organizational sciences (Adner, 2006; Mercan and Göktaş, 2011; Moore, 1993). It is mostly used on an organizational level, to study "the collaborative arrangements through which firms combine their individual offerings (i.e. technologies) into a coherent, customer facing solution" (p. 98) Adner (2006). According to Rubens et al. (2011, p. 1734) a successful innovation ecosystem enables a "goal-focused creation of new goods and services tailored to rapidly evolving market needs (i.e. technologies) with multiple institutions and dispersed individuals for parallel innovations".

This paper aims to use the literature on innovation ecosystems with system building in TIS. By more explicitly bringing in mechanisms and insights on the dynamics of parallel codependent technologies from the literature on innovation ecosystems, we aim to contribute to system building literature. We will provide new insights on how system building evolves within TIS and if/how it differs from single technology diffusion processes.

In order to study the role of co-dependent technologies in the context of other system building strategies, we have chosen to focus on areas where two technologies are heavily related to each other. We focus on system building activities by large pharmaceutical firms together with other involved stakeholders in the development and diffusion of an emerging technological field - new personalized cancer drugs and their corresponding companion diagnostics.

Personalized medicine (also called targeted, stratified or precision medicine) in oncology represents an emerging technological concept in biomedical innovation. It enables higher treatment efficacy and lower toxicity than conventional cancer treatments. This is possible because personalized medicines target only a specific cancer causing biomarker (i.e. mutation) in cancer patients' genes, proteins and pathways. This biomarker has been identified by companion diagnostics beforehand. This means that, in personalized medicine, co-development of diagnostic devices plays a central role. Treatment decisions depend heavily on the results of the testing assays, which act as stratification factors in identifying which patients can benefit from particular personalized cancer medicine (Fridlyand et al., 2013; Olsen and Jorgensen, 2014).

However, the progress towards realizing the potential of personalized medicine in oncology has been troublesome. This is particularly the case in England, which has witnessed one of the slowest uptakes of the first personalized breast cancer drugs and corresponding diagnostics in Western Europe. This is due to a number of systemic barriers in the English healthcare system to novel medical technologies (Miller et al., 2011; Wilking et al., 2009). Innovative actors carried out a number of system building activities over the years in order to overcome these obstacles and improve further uptake and diffusion. This paper combines the innovation ecosystem concept with the system building framework (i.e. actors' activities towards creating more supportive environments for emerging technologies). In doing so, it sheds light on how technological interdependencies between drugs and diagnostics and changing organizational dimensions influenced actors' system building strategies.

Therefore, the main research questions are:

- How can we understand the impact of technological complementarities, timing strategies and changing organizational complexity on system building within TIS that took place during the diffusion of the first personalized cancer therapeutics and corresponding companion diagnostics in England?

- What kind of strategies of system building by different actors can we identify regarding the improvement of the implementation and diffusion of these co-dependent technologies in modern healthcare systems?

The paper is structured as follows. In Section 2, we review the theory on technological innovation systems, system building and innovation ecosystems and explain our analytical framework. Section 3 addresses the methodology. The features of personalized medicine and the case description are elaborated in Section 4 . Section 5 covers the results of the empirical analysis of 
our framework. Section 6 concludes with answering the research questions.

\section{Theoretical background}

In the following chapter we introduce the system building concept in the technological innovation system framework and explain in more detail what the innovation ecosystem literature can contribute.

Rooted in evolutionary economics, the main principle of the innovation system line of thinking is that the main reasons for technological change are not only endogenous. Indeed, they are also found in the wider societal structure around innovative actors (Carlsson and Stankiewicz, 1991; Freeman, 1987; Lundvall, 1992). This means that firms and organizations do not innovate in isolation (Edquist, 1997), but interact and are part of a broader framework - i.e. innovation system (Lundvall, 1992).

The technological innovation system (TIS) concept emerged in the early nineties from a wider innovation system framework. It takes the processes of a system around one specific emerging technology as its analytical unit. According to Carlsson and Stankiewicz (1991, p. 111) TIS can be defined as a "network of agents interacting in a specific economic/industrial area under a particular institutional infrastructure or set of infrastructures and involved in the generation, diffusion, and utilization of technology". A more recent version by Bergek et al. (2008, p. 408) suggests that: "socio-technical systems focused on the development, diffusion and use of a particular technology (in terms of knowledge, product or both)".

The TIS framework includes different structural components, such as actors (1) and/or networks of actors (2), institutions (rules of the game) (3) and the interactions between them (Jacobsson and Bergek, 2004; Markard and Truffer, 2008a). These components commonly facilitate growth and development through the entrance of additional organizations, network development and institutional alignment (Weber and Rohracher, 2012).

Actors can be individuals or any kind of private company, research institute, university, intermediary organization, governmental organization or association. Institutions can be equally diverse - covering regulations e.g. laws, but also policy decisions, general principles, codes of conducts, values, and cognitive norms; all of which impact actors' activities (Edquist, 2005). Some authors have added technology as a fourth structural element to TIS (Suurs, 2009). Others argue that technology is an explicit outcome of different processes within innovation systems (Edquist, 2005). Furthermore, recently, knowledge (or system resources) has been proposed as additional structural element to be added to the TIS framework (Musiolik and Markard, 2011; Sandén and Hillman, 2011).

Further, the structural TIS analysis has been complemented with a dynamic perspective on innovation system development. This has been based mostly on work in the energy and sustainability field by Bergek et al. (2008) and Hekkert et al. (2007). This more dynamic perspective includes analysis of seven key processes resulted from different actor activities towards developing a TIS (Bergek et al., 2008; Hekkert et al., 2007) (see Table 1). All these seven key processes - which differ slightly depending on the respective author (e.g. Chaminade and
Edquist, 2010) - are important for a well functioning TIS (Hekkert et al., 2007).

The meso-level analytical focus of TIS studies is derived from the initial need to accompany the business literature in explaining the systemic and collective aspects of innovation (Carlsson et al., 2002; Jacobsson and Bergek, 2004). There is certainly a danger that such a system level analysis of structures and functions may overlook the influence of strategic micro-level activities by different actors on the system level (Truffer et al., 2012). Combining the TIS perspective with insights from actor strategies enables us to: 1 . Deepen understanding as to why certain actors decide to follow a specific strategy; 2 . Which consequences this brings (e.g. free-riding, burnout of the prime movers) and 3. How it impacts the diffusion of a specific technology in a TIS (Hellsmark and Jacobsson, 2009; Lieberman and Montgomery, 1988; Olleros, 1986).

Up to now, there are few TIS studies which have been conducted on specific actor roles within a TIS. The few examples there are include studies on firms (Cetindamar and LaageHellmann, 2002), networks (Musiolik et al., 2012) and individuals (Hellsmark and Jacobsson, 2009) as system builders. These all have illustrated the influence of the different system building activities of actors on overall system performance. System building can be a collective effort by a number of different actors (Garud et al., 2007) or carried out by one single powerful actor (Hughes, 1987). Additionally, Carlsson and Jacobsson have emphasized the specific role of early entrants' i.e. prime movers in a TIS, who can "...raise awareness, undertake investment in the new technology, give it legitimacy and diffuse it through various mechanisms to other actors" (Carlsson and Jacobsson, 1997, p. 305). Hellsmark and Jacobsson (2009) have proposed that the system building capacity of prime movers and other actors within a TIS could be analyzed by their ability to influence (i.e. improve) the seven key TIS processes (see Table 1) (Hellsmark and Jacobsson, 2009).

Musiolik et al. (2012) have defined this kind of system building by different actors in a TIS as "the deliberate creation or modification of broader institutional or organizational structures in a technological innovation system carried out by innovative

Table 1

Core processes within the TIS framework based on Hekkert et al. (2007).

\begin{tabular}{|c|c|}
\hline Function & Comments \\
\hline $\begin{array}{l}\text { Entrepreneurial } \\
\text { activities }\end{array}$ & $\begin{array}{l}\text { New entrants or diversified business strategy of } \\
\text { already existing companies }\end{array}$ \\
\hline $\begin{array}{l}\text { Knowledge } \\
\text { development }\end{array}$ & $\begin{array}{l}\text { Creation of new knowledge base. Some indicators } \\
\text { are R\&D projects, patents and investments in R\&D }\end{array}$ \\
\hline $\begin{array}{l}\text { Knowledge } \\
\text { diffusion }\end{array}$ & $\begin{array}{l}\text { Diffusion of new knowledge among actors via } \\
\text { workshops, meetings, conferences on a specific } \\
\text { technology topic }\end{array}$ \\
\hline $\begin{array}{l}\text { Guidance of the } \\
\text { search }\end{array}$ & $\begin{array}{l}\text { Government targets to positively affect the visibility } \\
\text { of specific technology among its users }\end{array}$ \\
\hline $\begin{array}{l}\text { Market } \\
\text { formation }\end{array}$ & $\begin{array}{l}\text { Niche markets, tax regimes and new standards to } \\
\text { create a competitive advantage for novel } \\
\text { technologies }\end{array}$ \\
\hline $\begin{array}{l}\text { Resource } \\
\text { mobilization }\end{array}$ & $\begin{array}{l}\text { Allocation of financial and human capital to make } \\
\text { knowledge production possible for a specific } \\
\text { technology }\end{array}$ \\
\hline $\begin{array}{l}\text { Creation of } \\
\text { legitimacy }\end{array}$ & $\begin{array}{l}\text { The number of interests groups and their lobby } \\
\text { activities, public opinion towards the technology }\end{array}$ \\
\hline
\end{tabular}


actors. It includes the creation or reconfiguration of value chains as well as the creation of a supportive environment for an emerging technology in a more general way" (Musiolik et al., 2012, p. 1035). However, the TIS studies on either the micro- or meso-level level focus their analysis traditionally around one specific technology, and do not consider technological interrelatedness (Markard and Truffer, 2008b). Therefore, when talking about technological innovation systems as sociotechnical systems, we also need to include and consider other relevant technologies in the innovation systems. This will allow us to better structure the context of the TIS and understand the dynamics of the TIS with several other codependent technologies. These kinds of parallel systems or technologies can affect the focal TIS in several ways. For example, they can be either complementary (i.e. symbiosis), competitive or both at the same time (Jacobsson, 2008; Sandén and Hillman, 2011; Truffer et al., 2012; Wirth and Markard, 2011).

There are already some works which look at how different technologies influence each other. However, the focus has been more on system level TIS-TIS interactions, not on interactions between two technologies within the same TIS. Islas (1997, p. 64) reported in his study on gas and steam turbines that "two technologies can be complementary and in competition at the same time and in the same market sector". Wirth and Markard (2011) analyzed a renewable energy TIS in Switzerland in relation to other technology fields that compete for the same biomass resources. Sandén and Hillman studied interactions between different transport fuel technologies in Sweden (Sandén and Hillman, 2011). Accordingly, there is already some evidence in the literature that besides competition, other kinds of interactions between technologies (i.e. complementarities) could be of great significance (Sandén and Hillman, 2011). However, this has not been developed any further within the TIS framework until now.

Unlike the TIS concept, the notion of "technological co-dependency" is heavily conceptualized in the innovation ecosystem framework, which is itself rooted in management and organizational literature (Adner, 2006; Moore, 1993). It is used mostly on an organizational level, to study "the collaborative arrangements through which firms combine their individual offerings into a coherent, customer facing solution" (Adner, 2006).

Therefore, the innovation ecosystem framework not only acknowledges that actors do not innovate in isolation and that they are interdependent (like the TIS approach). It further recognizes that they are developing products (i.e. technologies) that other actors depend on (Adner and Kapoor, 2010). This increases the complexity of the overall system. Since James Moore introduced the term 'business ecosystem' (Moore, 1993), the term 'innovation ecosystem' has gained currency within management science and academic literature on innovation and competition. An ecosystem is in essence a concept derived from nature that refers to an environment consisting of all the living, as well as non-living organisms and different components of the environment within these organisms communicate (Adner, 2006; Mercan and Göktaș, 2011). Based on this, Moore was the first to propose an analogy between the biological and business worlds (Moore, 1996).

Mercan and Göktaş (2011, p. 102) add that an "innovation ecosystem consists of economic agents and economic relations as well as the non-economic parts such as technology, institutions, sociological interactions and the culture". The last group, also called innovation structure, can enable idea creation, the introduction and the diffusion of innovation (Mercan and Göktaş, 2011). Ideally, a well functioning ecosystem "helps participants to operate beyond current boundaries" and to "enable transformation of knowledge into innovation” (Mercan and Göktaş, 2011, p. 102). Therefore an organizational dimension is closely related to the technological dimension in an innovation ecosystem - the complementary technologies are developed by organizations within the same system.

It is not completely clear which factors - besides the above introduced technological co-dependencies and organizational dimension are of key importance in innovation ecosystem development. Some relevant factors that have been identified include the resource allocation needed to make the transition from vision to reality (Zahra and Nambisan, 2012). Also, critical bottlenecks may reside outside the system and allocating resources externally can be almost as important as the allocation of resources internally (Adner, 2006).

Timing is another factor that innovation ecosystem literature focuses on. Getting to the market ahead of rivals is beneficial only if the other organizations and technologies/complementary products (those your product depends on) are ready when you arrive (Adner, 2006). Hughes (1987) has introduced the term "reverse salients", which are components (e.g. a technology) in the innovation systems that have fallen behind others. These systemic components fail to deliver the necessary level of performance and can therefore hinder the whole system development (Dedehayir and Mäkinen, 2008). Therefore, timing is an important factor that organizations need to take into account in their own strategy. It is not just a single track, but a complex work of interactions between different organizations that has a major impact on the technology one wants to diffuse. The notion of timing has not yet been taken up in the technological innovation system literature, nor in system building literature. However, we believe that the timing factor could be relevant for these concepts and should be looked into in more detail.

In this article, these different notions - borrowed from innovation ecosystems - will enable an analysis, of how complementary technologies, organizational interdependencies and timing strategies influence the system building activities that are directed towards development and diffusion of modern cancer therapeutics within a specific TIS.

\section{Methodology}

We have analyzed the importance of system building which creates favorable conditions for the diffusion process of two personalized medicine cancer drugs and their companion diagnostics within the TIS framework. Because Herceptin ${ }^{\circledR}$ and Tarceva ${ }^{\circledR}$ are among the first personalized cancer drugs, and therefore represent an emerging technological field, we have chosen to employ an explorative multiple case-study methodology to study their diffusion process from an innovation systems perspective. Our geographical delineation is England, because, this country has a very complex institutional environment for gaining market access for personalized cancer drugs and diagnostics due to very demanding assessment 
procedures of new therapeutics. Consequently, England had one of the slowest uptakes of early personalized cancer drugs and their companion diagnostics in Western Europe since the beginning of the last decade (Wilking and Jönsson, 2005).

Innovative actors - who were involved in this personalized medicine TIS - carried out a number of system building activities that eventually led to major changes in the TIS, which in turn significantly improved the further uptake and diffusion of these drugs. Because we knew in advance that very intensive system building had taken place regarding Herceptin ${ }^{\circledR}$ and its diagnostics, we wanted to learn whether the same strategies were also apparent for subsequent drugs i.e. Tarceva ${ }^{\circledR}$ and its corresponding diagnostics. Besides this, we analyzed how the involved actors dealt with different factors (e.g. technological co-dependency, timing and organizational complexity) and their influence on the overall TIS performance.

The time delineation of this case is the period from 2000 to 2012. In 2000, Herceptin ${ }^{\circledR}$ received European wide marketing approval and was introduced onto the English market as a late stage breast cancer therapeutic. Five years later, Tarceva ${ }^{\circledR}$ received marketing approval as a second line (i.e. after chemotherapy treatment) lung cancer therapeutic. We focus our analysis on the twelve-year period when the major system building activities took place - for both of the drugs and their companion diagnostics - which eventually lead to successful market uptake in England for Herceptin ${ }^{\circledR}$ as an early stage breast cancer drug in 2005 and eventually, in 2012 for Tarceva ${ }^{\circledR}$ as a first line lung cancer therapeutic.

We started our analysis by identifying and mapping all the relevant structural elements of the personalized medicine TIS in England: actors, networks and the institutions. Empirical data was collected retrospectively making use of various sources, such as scientific literature, "grey" literature (professional journals, reports, policy papers and books) and various websites. ${ }^{1}$ Search terminology comprised of the following words either on their own, or in combination: 'Herceptin' or 'Trastuzumab' or 'Tarceva' or 'Erlotinib' or 'HER2' or 'EGFR' or 'personalized medicine' or 'breast cancer' or 'NSCLC' or 'companion diagnostics' or 'England' or 'NICE'.

Thereafter, by using the same information sources, a qualitative event history analysis was carried out to detect important developments in the innovation process of personalized medicine and companion diagnostics. This method has already been successfully adopted by a number of TIS scholars (e.g. Boon, 2008; Negro et al., 2007). Initially developed by Poole et al. (2000) and Van de Ven (1990), the event history analysis enables us to analyze in a structured way complex data by gathering information as a sequence of different events that unfold over time (Suurs, 2009). In the current history event analysis, system level events that were influential to the development and diffusion of Herceptin ${ }^{\circledR}$ and Tarceva ${ }^{\circledR}$ in England over the period of 12 years were identified and systematically allocated to specific system

\footnotetext{
1 Examples of scientific literature sources: PubMed, Scopus, Web of Science; "grey" literature: annual reports and press releases of Roche and AstraZeneca, BusinessWeek, Genetic Engineering \& Biotechnology News; websites: www. astrazeneca.co.uk, www.roche.com, www.nice.org.uk.
}

building (i.e. system function) classes (Table 2). A narrative was thereafter constructed based on the events around the evolution of the personalized medicine TIS in England.

The composed narrative was then verified, partly reconstructed and developed further after including the insights from 9 semi-structured expert interviews (Table 3) and 15 interviews from earlier work (Kukk et al., submitted for publication).

The whole interview process was carried out through snowball sampling. We selected the first interviewees based on their background and area of expertise. These experts pointed towards additional experts to interview. By the end of the interview process we had included all the relevant stakeholder groups in our interview sample - industry, academia, drug regulation and medical practice were all involved in, or have thorough knowledge of, the diffusion process of personalized medicine cancer drugs and diagnostics in England. For each expert, we personalized the interview guide in advance based on their individual background and area of expertise. To explore the different actor strategies and understand their actual behavior and underlying motivation, we asked the experts a number of questions about the personalized medicine and companion diagnostics' market development in England in general, and about Tarceva ${ }^{\circledR}$ and Herceptin ${ }^{\circledR}$ in particular. We also asked the interviewees to characterize the regulatory environment of the market and how developments in this area have impacted the uptake of personalized medicine cancer drugs and diagnostics. The interviews were also used to map the main actors, involved in the diffusion process of Herceptin ${ }^{\circledR}$ and Tarceva ${ }^{\circledR}$ : their underlying motivation, the problems they had encountered and what kind of system building activities they had undertaken to overcome these problems.

Inconsistencies between the narrative and interviews were controlled with subsequent interviews to get a supplementary insight. Therefore the interview questions became more precise through the process. To increase the overall quality of the outcome, we also compared all our interview findings against the results of the original event database. In case of contradictions, we conducted additional data search, which combined all data sources mentioned in the above paragraphs.

\section{The development of personalized cancer medicine innovation systems in England}

In order to improve understanding of the impact of organizational, technological complexities and timing on system building strategies, we analyzed the developments around the innovation system of two consecutive personalized medicine cancer drugs (Herceptin ${ }^{\circledR}$ and Tarceva ${ }^{\circledR}$ ) and their corresponding companion diagnostics in England from 2000 until 2012. This takes us back to the introduction of the first personalized breast cancer medicine, Herceptin ${ }^{\circledR}$ - and its companion diagnostics - to the English market from 2000 until 2006, followed by the personalized lung cancer medicine Tarceva ${ }^{\circledR}$ and its companion diagnostics from 2006 until 2012. A number of different events took place around the diffusion process of these drugs and diagnostics that enable a better understanding of actor strategies in different circumstances in personalized medicine TIS. 
Table 2

Examples of events allocation to different system functions (based on TIS functions by Hekkert et al. (2007).

\begin{tabular}{|c|c|c|c|c|c|c|c|}
\hline EVENTS around Herceptin ${ }^{\circledR}$ & $\begin{array}{l}\text { Entrepreneurial } \\
\text { activities }\end{array}$ & $\begin{array}{l}\text { Knowledge } \\
\text { creation }\end{array}$ & $\begin{array}{l}\text { Knowledge } \\
\text { diffusion }\end{array}$ & $\begin{array}{l}\text { Guidance of } \\
\text { search }\end{array}$ & $\begin{array}{l}\text { Market } \\
\text { formation }\end{array}$ & $\begin{array}{l}\text { Resource } \\
\text { allocation }\end{array}$ & $\begin{array}{l}\text { Creation of } \\
\text { legitimacy }\end{array}$ \\
\hline Regulatory approval by EMA & & & & & $\mathrm{x}$ & & \\
\hline Positive assessment by NICE & & & & & $\mathrm{x}$ & & \\
\hline $\begin{array}{l}\text { Collaboration to develop } \\
\text { companion diagnostic }\end{array}$ & $\mathrm{x}$ & & & & & & \\
\hline Positive reimbursement decision & & & & & & $\mathrm{x}$ & \\
\hline Beginning of a clinical trial & & $\mathrm{x}$ & & & & & \\
\hline New scientific evidence published & & & $\mathrm{x}$ & & & & \\
\hline Launch of governmental strategy & & & & $\mathrm{x}$ & & & \\
\hline $\begin{array}{l}\text { Meeting organized about } \\
\text { Herceptin }{ }^{\circledR}\end{array}$ & & & $\mathrm{x}$ & & & & \\
\hline Supportive political statement & & & & & & & $\mathrm{x}$ \\
\hline
\end{tabular}

\subsection{Herceptin® and HER2 testing (2000-2006)}

Breast cancer is one of the most common type of cancers worldwide and the most common cause of cancer death next to lung cancer (Peters et al., 2012). Herceptin ${ }^{\circledR}$ tackles breast cancer cells that overexpress HER2 protein. Based on a positive assessment result by the European Medicine Agency (EMA), this therapeutic was the first personalized cancer medicine that received a European wide license from the European Commission in 2002 for the treatment of metastatic (i.e. late-stage) HER2 positive breast cancer. However, to market a drug in England, the EMA decision is not adequate. There is an additional prerequisite. For a therapeutic to be reimbursed by the National Health Service (NHS) in England a positive costeffectiveness assessment decision must be reached by the National Institute of Clinical Excellence (NICE) - an independent organization, which produces national guidelines on health technologies based on their clinical efficiency and costeffectiveness (OPSI, 1999). Since NICE was established in 1999, Herceptin ${ }^{\circledR}$ was the first personalized cancer medicine to undergo NICE's review process. This lasted a very long time almost three years (NICE, 2002). During that time - between 2000 and 2002 - the drug had an EU wide license and could be prescribed to patients. However, it was not covered under the NHS budget and reimbursement decisions were made on a case by case basis on a local level (Mayor, 2005).

In personalized medicine, therapeutics and companion diagnostic are highly co-dependent, meaning that neither of these technologies can diffuse without the other and the fast uptake of either of these technologies is vital for the diffusion of other. In the case of Herceptin ${ }^{\circledR}$, the HER2 protein is considered a prognostic factor as it is over-expressed in $25-30 \%$ breast

Table 3

Overview of interviewees.

\begin{tabular}{lll}
\hline ID & Type of actor & Date of interview (by phone) \\
\hline A & Industry executive & $04-03-2014$ \\
B & Industry executive & $03-03-2014$ \\
C & Regulatory agency representative & $07-03-2014$ \\
D & Pathologist & $24-03-2014$ \\
E & Oncologist & $21-03-2014$ \\
F & Oncologist & $15-05-2014$ \\
G & Cancer charity representative & $13-05-2014$ \\
H & Researcher & $04-03-2014$ \\
I & Oncology pharmacist & $26-02-2014$ \\
\hline
\end{tabular}

cancer patients, meaning that diagnosing the HER2 status in tumor cells is the only way to identify patients who could benefit from Herceptin ${ }^{\circledR}$ treatment (NICE, 2002). This makes these two technologies highly co-dependent on each other. Roche - the manufacturer of Herceptin ${ }^{\circledR}$ - undertook a number of different system building activities around Herceptin ${ }^{\circledR}$ and HER2 testing (see Table 4). With all these activities, the aim was to stimulate a fast and high level uptake of this new type of drug as soon as it had received a positive opinion from NICE and was included in the NHS reimbursement scheme (Hedgecoe, 2004).

Breast cancer is a disease with a very high profile and has one of the most powerful charity support and patient lobbies in the world. Roche benefited greatly from this situation by skillfully engaging different stakeholder groups in the breast cancer TIS in order to work on parallel technological trajectories simultaneously - supporting the diffusion process not only of the therapeutic, but also of the diagnostic (see Table 4). These activities already started before Herceptin ${ }^{\circledR}$ was licensed in Europe in 2000.

In 1998, Roche signed a contract with a small diagnostic company, Dako, in order to develop an effective and high quality diagnostic technology to detect HER2 status in breast cancer patients (Genentech, 1998) (Table 4). A year later, the company carried out a market study on HER2 testing in the UK (Enzing et al., 2006; Kukk et al., submitted for publication) (Table 4). The results indicated that only around $6 \%$ of the metastatic breast cancer patients were tested for HER2 (Enzing et al., 2006). The clear message for Roche was that, in order to support the uptake of Herceptin ${ }^{\circledR}$, only HER2 testing technology development was not sufficient and a lot of system building work would still be necessary in order to significantly improve HER2 testing diffusion in the English market.

Thereafter, resources were mobilized and Roche started supporting three HER2 testing centers: Nottingham City Hospital, Glasgow Royal Infirmary and Royal Marsden Hospital in London provided free HER2 testing for all the breast cancer patients throughout the country (Ellis et al., 2000) (Table 4). This activity was soon combined with an additional initiative an expanded access program (EAP) for Herceptin ${ }^{\circledR}$, to give 168 patients in 32 different centers across UK free of charge Herceptin ${ }^{\circledR}$ with or without chemotherapy and to assess the safety of the drug on HER2 positive patients (Miles and Wroath, 2001; Papazisis et al., 2004) (Table 4). Additionally, starting a 
Table 4

Main system building events around Herceptin ${ }^{\circledR}$ and companion diagnostics.

\begin{tabular}{|c|c|c|c|}
\hline EVENTS around Herceptin ${ }^{\circledR}$ & Time & $\begin{array}{l}\text { System building for } \\
\text { therapeutic }\end{array}$ & $\begin{array}{l}\text { System building for } \\
\text { companion diagnostics }\end{array}$ \\
\hline Collaboration with Dako to develop companion diagnostic for Herceptin ${ }^{\circledR}$ & 1998 & & $\mathrm{X}$ \\
\hline Market study by Roche to analyze HER2 testing routines & 1999 & & $\mathrm{X}$ \\
\hline Roche sponsored three HER2 testing centers in Nottingham, Glasgow and London & 1999-2003 & & $\mathrm{X}$ \\
\hline Expanded access program for Herceptin ${ }^{\circledR}$ & 2000 & $\mathrm{X}$ & \\
\hline Knowledge diffusion in medical community & $2000-\ldots$ & $\mathrm{X}$ & $\mathrm{X}$ \\
\hline Knowledge diffusion in non-medical community & $2000-\ldots$ & $\mathrm{X}$ & $\mathrm{X}$ \\
\hline Collaboration between Roche and 34 Cancer Networks & 2005-2006 & & $X$ \\
\hline
\end{tabular}

few months later, Roche temporarily offered hospitals an opportunity to purchase the drug directly from the producer at lower price (Hedgecoe, 2004) (Table 4).

Around 2005 new scientific evidence emerged that Herceptin $\circledast$ could also be used for early stage HER2 positive breast cancer patients (Tuma, 2005). Since women with early stage breast cancer were not commonly tested for HER2 at that time, it was obvious that the demand for HER2 would increase substantially once the drug became licensed for this additional indication (Dowsett et al., 2007). In order to meet the increasing need for HER2 testing, Roche started collaborating with the 34 public Cancer Networks that had been initially set up in 2001 by the NHS to facilitate patients' involvement in oncology clinical trials (Hedgecoe, 2004) (Table 4). Roche provided these networks with training, general funding or free HER2 testing - investing in total around $£ 1.5$ million (Kanter, 2005) and increased HER2 testing from 31 to $91 \%$ by 2006 (Pharmaceutical Field, 2008), when the drug got included in the NHS reimbursement scheme for early stage breast cancer.

This case demonstrates clearly that Roche had understood the importance of technological co-dependence of this personalized breast cancer medicine and corresponding diagnostic test. We have witnessed how the company undertook different system building activities in order to overcome hindrances in both complementary technologies that could delay the overall adoption of these technologies within a TIS. Since Roche was the first system builder in this TIS, it worked on both technological trajectories simultaneously and took care of all the necessary system building work - regarding the drug and diagnostic - itself.

\subsection{Tarceva® and EGFR-TK testing (2005-2012)}

Lung cancer is the most common cause of cancer death next to breast cancer (Peters et al., 2012). The majority of lung cancers (i.e. 80-85\%) are specific types of non-small-cell lung cancer (NSCLC) (Peters et al., 2012). Tarceva ${ }^{\circledR}$ (the brand name for erlotinib) is a NSCLC small molecule drug that inhibits the epidermal growth factor receptor tyrosine kinase (EGFR-TK), which is over-expressed in around 16\% of NSCLC cancer patients' tumor cells (Rosell et al., 2012), thus slowing the further growth of tumor cells. Like Herceptin ${ }^{\circledR}$, Tarceva ${ }^{\circledR}$ also represents a new type of "personalized" drugs - because it only has an effect on a specific molecular target that causes tumor growth (i.e. EGFR-TK) that can be only identified by using a specific companion diagnostic technology.

Around the same time Herceptin ${ }^{\circledR}$ was licensed in Europe for early stage HER2 positive breast cancer treatment in 2005 Tarceva ${ }^{\circledR}$ was also licensed in Europe for the treatment of locally advanced or metastatic NSCLC as a second line treatment (e.g. after the failure of at least one treatment scheme of chemotherapy) for all patients, irrespective of a patient's EGFR exact status, as long as it was expressed on the cancer cell surface (Roche, 2005). As many tumor cells have too many EGFRs (i.e. EGFR is "over-expressed"), then the idea behind Tarceva ${ }^{\circledR}$ was that blocking the EGFRs would also slow down cancer growth and statistically increase median survival (Herper, 2009). This meant that there was no direct need for a specific companion diagnostic technology development. In 2005, when Tarceva ${ }^{\circledR}$ received the European license as a second line treatment for NSCLC patients, there were already a number of other expensive personalized cancer medicine products (i.e. Avastin ${ }^{\circledR}$, Tykerb ${ }^{\circledR}$, Erbitux ${ }^{\circledR}$ ) ready to be introduced to the English market and Tarceva ${ }^{\circledR}$ underwent NICE assessment together with them - all competing for the same NHS budget. In May 2006, NICE started its first cost-effectiveness assessment procedure for Tarceva ${ }^{\circledR}$ (Roche, 2006). By the end of 2007 NICE had issued two negative assessments. According to its threshold, Tarceva ${ }^{\circledR}$ did not prove to be cost-efficient enough to be included in the NHS reimbursement scheme (McKee, 2007). Besides knowledge diffusion in medical community, as an temporary market creation measure, Roche lowered the price of Tarceva ${ }^{\circledR}$ by $27 \%$ - until a positive opinion from NICE (McKee, 2007) - in order to enable hospitals to purchase the drug directly from the company at a lower price (Table 5). Eventually Roche agreed to lower the official price of a 125-day Tarceva ${ }^{\circledR}$ treatment from $£ 6,800$ to $£ 6,128$, to have the price at same level as the chemotherapy drug Taxotere ${ }^{\circledR}$ - used for the same indication (Table 5). Thereafter it received a positive opinion from NICE and was included in the NHS scheme for use by NSCLC patients as an alternative to Taxotere ${ }^{\circledR}$ as a second line treatment (NICE, 2008).

Soon after the launch of Tarceva ${ }^{\circledR}$ on the English market in 2008 , additional promising scientific evidence emerged about its affect on progression free survival when used as a first line treatment for those patients who tested positive for a specific EGFR-TK mutation (Rosell et al., 2012) (Table 5). Ideally, a personalized medicine and its companion diagnostic should be launched on the market simultaneously, as was the case for Herceptin $₫$ in 2002. However, when Tarceva ${ }^{\circledR}$ was first licensed in the EU as a second line treatment in 2005, there was only vague scientific evidence available that the drug might work better for certain NSCLC sub-populations, and that it was more effective on some patients than chemotherapy. Therefore the efficiency and value of the drug was lower (i.e. less cost-efficient), since there was no scientific knowledge or 
Table 5

Main system building events around Tarceva® and companion diagnostics.

\begin{tabular}{|c|c|c|c|}
\hline EVENTS around Tarceva ${ }^{\circledR}$ & Time & $\begin{array}{l}\text { System building for } \\
\text { the therapeutic }\end{array}$ & $\begin{array}{l}\text { System building for } \\
\text { companion diagnostics }\end{array}$ \\
\hline Roche lowered the price of Tarceva ${ }^{\circledR}$ by $27 \%$ & 2007 & $\mathrm{X}$ & \\
\hline Roche enabled hospitals to purchase the drug directly at lower price & 2007 & $\mathrm{X}$ & \\
\hline AstraZeneca sponsored testing centers & 2009-2010 & $\mathrm{X}$ & \\
\hline Knowledge diffusion in medical community & 2007 onwards & $\mathrm{X}$ & \\
\hline Iressa ${ }^{\circledR}$ increased effectiveness on EGFR-TK mutation & 2009 & $\mathrm{X}$ & \\
\hline AstraZeneca collaboration with DxS to develop TheraScreen ${ }^{\circledR}$ : EGFR 29 mutation Kit & 2009 & & $\mathrm{X}$ \\
\hline AstraZeneca supporting EGFR-TK testing & 2010-2012 & & $\mathrm{X}$ \\
\hline AstraZeneca supported quality control and validation of testing & 2010-2012 & & $\mathrm{X}$ \\
\hline AstraZeneca set up the website for EGFR-TK testing & 2010 & & $\mathrm{X}$ \\
\hline AstraZeneca set up iPhone app to support EGFR-TK testing & 2010 & & $\mathrm{X}$ \\
\hline Roche developed Cobas EGFR Mutation Testing Kit & 2011 & & $\mathrm{X}$ \\
\hline
\end{tabular}

complementary technology developed that would have helped to prove its higher value. Solid scientific evidence about the higher effectiveness of Tarceva ${ }^{\circledR}$ in patients whose tumors had the mutated form of EGFR - in around 10\% Caucasian NSCLC patients (Galbraith, 2013) - only emerged in 2009 (Rosell et al., 2009). Even though, according to one of the interviewed experts, the sufficient scientific evidence may already have been available, it was presumed to be easier to market a drug without diagnostics that would not require setting up a whole additional (testing) system (Pathologist D). The latter was the strategy that Roche followed in 2005 when bringing Tarceva ${ }^{\circledR}$ to market as a second line treatment without a companion diagnostic. Additionally, without specific diagnostics, the potential patient group is larger, since it is not limited only to patients who test positive for a specific biomarker (e.g. EGFRTK, HER2) (Pathologist D). Therefore there was no formal obligation for EGFR-TK mutation testing when prescribing Tarceva ${ }^{\circledR}$ until 2011, when it was licensed in the EU as a first line treatment for those NSCLC patients who tested positive for the EGFR-TK mutation (Roche, 2011).

The Tarceva ${ }^{\circledR}$ case illustrates how many less resources and system building activities were needed from Roche in the absence of technological co-dependencies. From 2005 until 2008 , the company could devote on market creation for the personalized lung cancer medicine and did not have to dedicate any resources to build up a companion diagnostic system in England for Tarceva ${ }^{\circledR}$ as it had needed to for Herceptin ${ }^{\circledR}$ in 2002 to prevent the overall delay of adoption of this TIS.

\subsection{Timing strategies in system building}

As we have witnessed in the case of Herceptin ${ }^{\circledR}$ and HER2 testing, the system building work on diagnostic kits needed to be well aligned to the other system building activities towards the drug. Furthermore, we have seen that some system building activities on diagnostic development can even precede system building activities on the corresponding drug. As we will illustrate below, the timing strategies in system building can sometimes relate even further from a drug and its' companion diagnostic to the wider TIS.

In parallel to Tarceva ${ }^{\circledR}$, an additional NSCLC personalized medicine drug - Iressa ${ }^{\circledR}$ (the brand name for Gefitinib) was developed by another pharmaceutical company - AstraZeneca (Fig. 1). Iressa ${ }^{\circledR}$ was very similar, almost identical, to Tarceva ${ }^{\circledR}$ as it worked for the same indication. It is important to know that in 2004, AstraZeneca had already applied for a license for Iressa ${ }^{\circledR}$ in Europe, but eventually withdrew its application since it worked for only around $10 \%$ of patients.

Unlike Roche did for Tarceva ${ }^{\circledR}$, AstraZeneca was unable to demonstrate that the drug significantly prolonged the survival of the overall clinical trial population (Comis, 2005).

Five years later, in 2009, a study in the New England Journal of Medicine was published, suggesting that specific companion diagnostic tests for specific mutations (i.e. EGFR mutations) could help to match the drug to a specific subtype of NSCLC patient, who would most benefit from Iressa ${ }^{\circledR}$ (Rosell et al., 2009). The companion diagnostic helps to identify the group of 10 to $15 \%$ of NSCLC patients who can benefit of the most and also increases the cost-efficiency of this expensive drug. Based on this new scientific information, AstraZeneca applied for a license in Europe and in 2010, Iressa ${ }^{\circledR}$ received a positive assessment from NICE as a cost-effective first-line NSCLC therapeutic.

The same NICE assessment for Iressa ${ }^{\circledR}$ stated that the EGFRTK testing service in England was very problematic and underdeveloped and "...not routinely carried out in UK clinical practice at present..." (NICE, 2010, p. 24). For personalized medicines, it is not sufficient to have the right testing technology available if there is no infrastructure in place in the healthcare system to deliver test results to the patient and the treating oncologist at the necessary speed (Galbraith, 2013). The underdeveloped EGFR-TK testing system can be explained by the fact that such testing had not been necessary before because there were no EGFR-TK specific therapeutics available. There had certainly been some lessons learned about the importance of companion diagnostics to Herceptin $\circledast$, HER2 testing and the amount of resources it takes to set up a specific testing system alongside a therapeutic. Since HER2 and EGFR-TK tests are technologically very different, and require different kinds of technology, the necessary system building by AstraZeneca had to start from scratch and "...the majority of the learning had to be done all over again" (Oncology pharmacist I).

Since AstraZeneca's drug Iressa ${ }^{\circledR}$ received a positive NICE assessment before Tarceva ${ }^{\circledR}$ (2010 vs. 2012), the company had to become the prime mover in EGFR-TK testing systems build up, and had to allocate the resources to develop the testing kit in collaboration with a diagnostic company DxS (GenNews, 2009), and to set up the whole EGFR-TK testing service in England (Table 5). In collaboration with twelve laboratories in England, AstraZeneca implemented the testing service to 


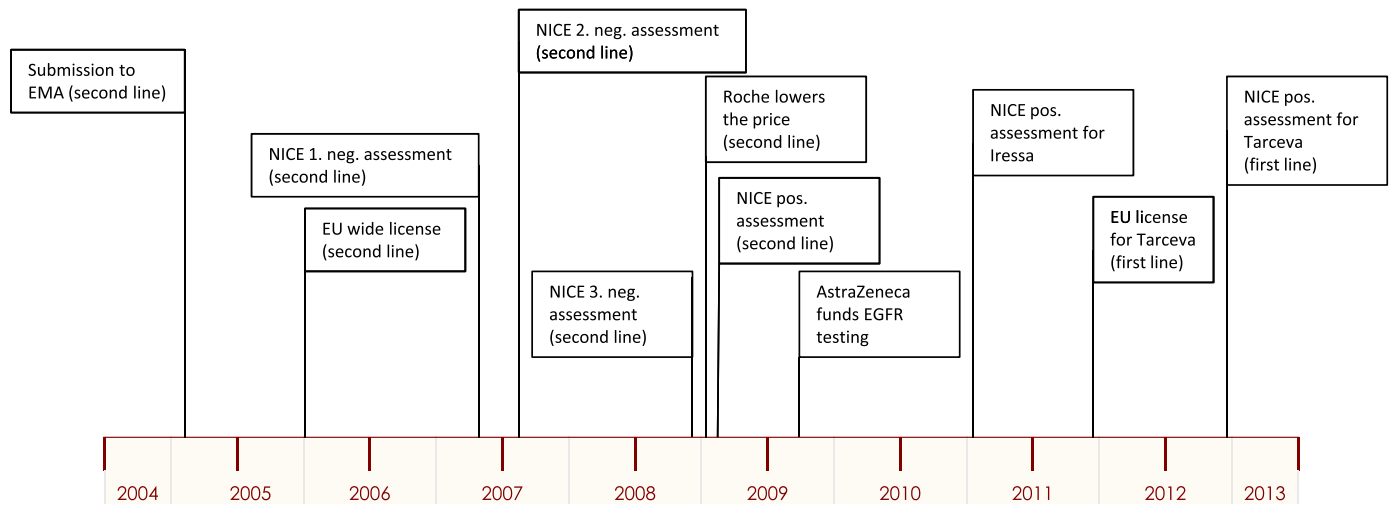

Fig. 1. Milestones of Tarceva ${ }^{\circledR}$, Iressa ${ }^{\circledR}$ and EGFR mutation testing in England.

prevent the underdeveloped EGFR-TK testing system becoming a barrier to the uptake of its drug (i.e. Iressa ${ }^{\circledR}$ ) (The Department of Heath, 2012) (Table 5). AstraZeneca's key activities included not only paying for EGFR-TK testing, but also setting up the whole testing system - taking care of quality control and validation of testing (Oncology pharmacist I). This included the setting up of the website (www. egfr-info-co.uk) to provide more information for healthcare professionals and raise their awareness of EGFR testing (Adams, 2010) (Table 5). The company also launched an iPhone application to provide educational resources and medical recommendations to facilitate patient access to EGFR testing (POST, 2012) (Table 5). By summer 2011, EGFR mutation testing had risen from 7000 to 8000 tests per year in the UK (Nicholson, 2013). In the same year, AstraZeneca received a Healthcare Collaboration Award for establishing a network for EGFR genetic testing centers in partnership with the NHS (PMlive, 2011). In this respect, AstraZeneca followed a similar strategy to Roche when they set up the testing system for HER2 in 2002.

This system building work by AstraZeneca was two years before Tarceva ${ }^{\circledR}$ has been given the EU wide license as a first line NSCLC therapeutic (Hallam, 2012). In 2012, NICE issued a positive opinion on Tarceva ${ }^{\circledR}$ as a first line treatment for patients who also test positive for the EGFR-TK mutation, as long as the manufacturer provides the drug at a lower price as agreed under the confidential patient access scheme (PAS) (NICE, 2012). Some months in advance, Roche announced that their in-house developed Cobas EGFR Mutation Test had been CE marked and would be available in all countries which recognize the CE mark (Roche, 2011). AstraZeneca acted on these developments “...by stopping any kind of EGFR-TK testing support in England on very short notice" (Pathologist D) as soon as Roche applied to extend the label for Tarceva ${ }^{\circledR}$ to include first-line treatment of patients whose tumors tested positive for EGFR activating mutations. Furthermore, the same NICE assessment document about Tarceva ${ }^{\circledR}$ concluded that, unlike in 2010 when AstraZeneca brought Iressa ${ }^{\circledR}$ onto the English market, by 2012, EGFR-TK mutation testing in England was at a good level and no further special measures were needed to help further diffusion of EGFR-TK testing (NICE, 2012). This illustrates the successful work on knowledge diffusion and capacity building that AstraZeneca had done together with regional laboratories and the Department of Health for setting up the EGFR-TK testing system for Iressa ${ }^{\circledR}$.

We have shown that since the same testing system was also used for Tarceva ${ }^{\circledR}$, Roche, did not have to do all the work and resource allocation that was necessary for HER2 testing back in 2002. Roche benefited greatly from the system building work done by its competitor AstraZenaca by using the already present testing facilities for testing for EGFR mutation and prescribing Tarceva ${ }^{\circledR}$ as a first line treatment for NSCLC patients on the NHS (Researcher $\mathrm{H}$ ).

Even though the conditions for Roche to carry out system building to support the uptake and diffusion of Tarceva ${ }^{\circledR}$ were harder in relation to organizational complexity, the company gained a lot in terms of companion diagnostic system building. Due to favorable timing strategy, the drug's competitor had already done a majority of the essential system building for Roche and had set up the necessary testing systems for Tarceva ${ }^{\circledR}$.

\section{Findings and theoretical implications}

As highlighted in the theory part, system building is important within innovation systems and firms need to engage themselves in all sort of different activities (e.g. networking, resource allocation, knowledge development and diffusion). However, from a strategy point of view, we lack insight as to the most efficient strategy for system building given specific circumstances.

We build our analysis on Hellsmark and Jacobsson (2009), who propose that system building (e.g. transformative capacity) can be analyzed by looking at the actors' ability to strengthen the seven key processes in innovation systems. Focusing not only on the development stage, but also including the diffusion and use of technology in the analysis, brings us closer to the overall socio-technical systems thinking in general. This thinking also emphasizes the role of entrepreneurs as system builders (Geels, 2004; Hughes, 1987). We analyze, therefore, in this article how technological co-dependencies, organizational complexity and timing influence the activities of entrepreneurs directed towards system building for personalized cancer medicines and their corresponding companion diagnostics' TIS in England. Our analysis provides first insights as to how these factors influence system builders when introducing an emerging technology into 
a modern healthcare landscape. In order to better understand the impact on personalized cancer medicine and companion diagnostic system building strategies, we take a closer look at our empirical findings.

In personalized cancer medicine, the two emerging technologies - therapeutics and diagnostics - are highly codependent and closer to each other than ever before. Therefore, we expected that technological co-dependence would play a big role in actor strategies aimed at market creation for personalized cancer medicines. We therefore chose to include the idea of technological co-dependency - taken from innovation ecosystems literature - in our analysis to deeper our understanding of system building strategies in an emerging technology innovation system. The first case - Herceptin ${ }^{\circledR}$ and HER2 testing - demonstrates clearly that the entrepreneur had fully understood the importance of technological co-dependence. It also shows that they understand that challenges in complementary technologies (i.e. diagnostics) could delay the overall adoption within a TIS. Since no other personalized medicine product had entered the English market before Herceptin ${ }^{\circledR}$, Roche was the first player (i.e. prime/first mover) in this TIS. The company enjoyed a lack of competition in system building activities. At the same time it had to overcome the typical challenges attached to first movers: technological challenges but also big resource investment over time to have the supporting infrastructure in place and the willingness of the potential adaptors to use the novel technology. The company worked on both technological trajectories in parallel (i.e. therapeutic and diagnostic developments). It also took care of all the necessary system building work - regarding the drug and diagnostic - itself. Even though the HER2 testing kit was de facto developed by Dako, it was Roche who outsourced this service and later took care of the implementation of the diagnostic technology without any significant external contribution. Therefore, Roche did not depend on other firms developing complementary products for their technology (i.e. HER2 testing) but took care of the two different technological trajectories itself. By doing this Roche prevented certain system components from falling behind of others, i.e. the development of "reverse salients" (Hughes, 1987). As a first mover, the company not only focussed on technological progress but also created features that enabled it to create value for its technologies. This demonstrates that a technological transition not only involves substitutions in technologies, but also changes in other elements, such as user practices, because they have to integrate new technologies into their working habits and routines. This becomes more complex and resource demanding as the co-dependency of different technologies increases. This kind of reliance between technological codependence and system building work has not been the focus on TIS scholars until now.

However, as our work indicates, besides technological interdependence, additional dimensions of the innovation ecosystem - such as organizational complexity - matter for system building strategies (Table 6). This means that the activities actors undertake within a system strongly depend on the organizational setting. If an actor is on its own, like Roche in Herceptin ${ }^{\circledR}$ 's case - it is down to this one actor to do all relevant system building work. If there are several firms that share the same interests, they could decide to share the technological and structural burden. As we will illustrate below, if there are firms with both diverging and common
Table 6

Influence of different complexities on system building in personalized medicine TIS based on seven system functions (Hekkert et al., 2007).

\begin{tabular}{|c|c|}
\hline $\begin{array}{l}\text { System building activities directed } \\
\text { towards TIS improvement }\end{array}$ & $\begin{array}{l}\text { Influence of technological co- } \\
\text { dependency, organizational } \\
\text { complexity \& timing }\end{array}$ \\
\hline $\begin{array}{l}\text { Undertaking entrepreneurial } \\
\text { activities towards novel } \\
\text { products and business models }\end{array}$ & $\begin{array}{l}\text { Technological co-dependency } \\
\text { increases the need for novel } \\
\text { business models that include } \\
\text { higher level of collaboration and } \\
\text { interdependence of different } \\
\text { companies. }\end{array}$ \\
\hline $\begin{array}{l}\text { Creating new knowledge, } \\
\text { combining new and existing } \\
\text { knowledge }\end{array}$ & $\begin{array}{l}\text { Technological co-dependency } \\
\text { requires increased knowledge } \\
\text { creation, organizational } \\
\text { complexity could facilitate the } \\
\text { process as it offers additional } \\
\text { possibilities for collaboration, at } \\
\text { the same higher degree of } \\
\text { coordination needed, if the parallel } \\
\text { technologies are developed by } \\
\text { different actors. }\end{array}$ \\
\hline $\begin{array}{l}\text { Diffusion of knowledge through } \\
\text { networks }\end{array}$ & $\begin{array}{l}\text { Higher knowledge diffusion } \\
\text { necessary, since more different } \\
\text { actor groups are likely to be } \\
\text { involved, especially if the new co- } \\
\text { dependent technological product } \\
\text { differs greatly from already } \\
\text { established technologies }\end{array}$ \\
\hline Influencing the guidance of search & $\begin{array}{l}\text { No significant differences between } \\
\text { single and co-dependent } \\
\text { technologies. }\end{array}$ \\
\hline Defining and creating market & $\begin{array}{l}\text { No significant differences between } \\
\text { single and co-dependent } \\
\text { technologies. }\end{array}$ \\
\hline Attracting and allocating resources & $\begin{array}{l}\text { High resource allocation needed, } \\
\text { especially from the prime mover, } \\
\text { since the organizational } \\
\text { complexity is lower in the } \\
\text { beginning, therefore collaboration } \\
\text { and cost sharing opportunities are } \\
\text { also lower. Less resources are } \\
\text { required from actors who join in } \\
\text { later, when the relevant } \\
\text { infrastructure is already created. }\end{array}$ \\
\hline $\begin{array}{l}\text { Creating legitimacy for new } \\
\text { technologies }\end{array}$ & $\begin{array}{l}\text { No significant differences between } \\
\text { single and co-dependent } \\
\text { technologies. }\end{array}$ \\
\hline
\end{tabular}

interests they might develop a coordinated strategy, or wait until others have done the hard work and then "join in". In the second case we witnessed the same kind of system building strategy by AstraZeneca for Iressa ${ }^{\circledR}$ (developing and building up the whole system for its drug and diagnostic) as Roche had earlier done for Herceptin ${ }^{\circledR}$. From Roche's perspective, the complexity of this innovation system had certainly increased. Additional actors (i.e. AstraZeneca) had entered the system and developed competing products (i.e. Iressa $\left.{ }^{\circledR}\right)$, but also codependent products (i.e. EGFR testing). Since both of these drugs needed the same testing technology, AstraZeneca, as a first mover in the EGFR testing, also did the necessary system building work for Roche by setting up the necessary EGFR testing system. It allocated resources and changed the cognitive institutions (i.e. testing routines and habits of medical community) that were initially a component which had strongly underperformed. In this case, AstraZeneca did all the necessary system building work for Iressa ${ }^{\circledR}$ and EGFR testing alone, while Roche was tied up in the process of getting market 
access for its product. This also illustrates the importance of existing rules and regulative institutions in a highly regulated market such as the pharmaceutical sector. Even if the company wanted to, it could not pursue any system building strategy since it did not have regulatory approval to bring its products to market. This situation was completely different from the Herceptin ${ }^{\circledR}$ case for Roche, where it had to do all the system building on its own. However, as soon as it was clear that Roche's Tarceva ${ }^{\circledR}$ would be launched on the English market with a compulsory companion diagnostic, AstraZeneca stopped supporting the EGFR testing system. Suddenly AstraZeneca was no longer the only company who needed EGFR testing. Also there was no incentive to provide sole support for the whole EGFR testing system if competitors could also take advantage of it for their own products. A less ambitious role can be associated with Roche regarding EGFR testing, which however, also needs a strategy regarding how strongly to commit to system building and the right time to enter the system. In the current case, there were some common and some divergent interests between the actors. One can also argue that if the actors (i.e. Roche and AstraZeneca) had wanted to, they could have developed a coordinated strategy in order to share the burden of setting up the diagnostic system. However, in this particular case no collective action was pursued and there was no coordination between actors in developing and implementing strategies towards improving the overall functioning of the TIS.

Another important factor is timing. We can see that the importance of timing grows as the organizational complexity increases within a system as the number of variables to take into account increases (Table 6). Depending on whether there is one actor moving alone, or several firms with common and diverse interests, the timing issue becomes increasingly important. We witnessed how companies need a well defined strategy not only for creating favorable conditions for the diffusion of their technologies but even more to transit the whole innovation system from one to another. Herceptin ${ }^{\circledR}$ could only be given to those patients who tested positive for the HER2 mutation. Accordingly, Roche knew they had to develop the drug and testing kits and also make sure that both of these products would be ready for launch onto the market at the same time. In the later Tarceva ${ }^{\circledR}$ case, we see that majority of system building work on EGFR diagnostics had already been done by another firm by the time Roche reached the market with its product. This enabled Roche to reduce investment in the diagnostic diffusion process. We do not know whether this was on purpose. However, it illustrates a possible system building strategy where certain actors delay the launch of their technology until the complementary parts are in place. This also illustrates that the market is simply not "out there" as some innovation studies assume (Geels, 2002, 2004). It is created by system builders, with timing being an important factor that influences entrepreneurs' strategic market creation activities. It is often assumed that companies are dedicating a lot of resources in order to be the first to introduce novel technologies to the market. We witnessed that technological innovation is not always about speed, but also about the right timing strategy that depends on the other technologies already in place and that in turn can impact the overall TIS development. This novel insight has not been visible in innovation system's literature yet.
As we can see, system building strategies are not a linear, but involve a complex set of interactions that together have a major impact on the technology one wants to bring to the market.

\section{Conclusions}

If we want to better understand how systems evolve, we need to have more insight into the patterns and strategies of different actors' activities. The current paper has taken the first steps in this direction. It extends our current understanding of how different complexities influence actor strategies in system building in technological innovation systems. More specifically, the paper illustrates how system builders within the TIS deal with the different technological co-dependencies and organizational complexities in their strategic activities.

We have used innovation ecosystem literature in order to create more insight into system building strategies in the current case study on personalized cancer therapeutics and diagnostics. This work has contributed to the literature on technological innovation systems and towards better understanding of different actor strategies. We have further developed the system building framework by including notions that take into account technological complementarities, organizational complexity and timing.

We have illustrated that technological complementarities play a major role in system building strategies as they demand massive resource investment to developing and diffuse parallel technologies. This is necessary in order to make sure that once a product reaches the market, the critical complementary components are already in place. Also, technological and organizational complexity seems to increase the development challenges for the entrepreneur. The innovator needs to overcome additional challenges in establishing additional sub-system within the TIS by integrating additional components into the system. This also illustrates the importance of timing in system building strategies. In the case of codependency, a technology only has maximum value for the market if the complementary product has been launched at the right time.

Also, the organizational setting plays a role in system building strategies and has an impact on how firms operate whether they pursue their goals alone or collaborate with others. In the current work, we have witnessed that, as soon as a competitor enters the market, the incentive to create complementary structures decreases for the first actor in the system. Therefore the strategy for investing resources decreases immediately as additional actors benefit from the already established system.

The current work, of course, is not without limitations. Since this research is based on a single industry, its replication in other sectors would increase the generalizability and validity of our results. Additional work would be also necessary to gain insight into micro level firm-internal strategies and also into how different firms in different circumstances deal with system building strategies. Under which conditions would coordination between the actors in their system building activities for co-dependent technologies become more central? Which type of strategies work best and in which type of circumstances? How do the actions actors take relate to complementary technologies, dealing with organizational complexity and 
timing? We hope that our analysis and findings can offer novel research paths along which different complexities in system building can be further addressed.

\section{References}

Adams, B., 2010. Digital pharma: AZ launches its first UK iPhone app. Pharmafile 8th December 2010.

Adner, R., 2006. Match your innovation strategy to your innovation ecosystem. Harv. Bus. Rev. 84 (4), 98-107.

Adner, R., Kapoor, R., 2010. Value creation in innovation ecosystems: how the structure of technological interdependence affects firm performance in new technology generations. Strateg. Manag. J. 31 (3), 306-333.

Bergek, A., Jacobsson, S., Carlsson, B., Lindmark, S., Rickne, A., 2008. Analyzing the functional dynamics of technological innovation systems: a scheme of analysis. Res. Policy 37 (3), 407-429.

Boon, W., 2008. Demanding Dynamics. Demand Articulation of Intermediary Organisations in Emerging Pharmaceutical Innovations (PhD Thesis) Department of Innovation Studies, Utrecht University, Utrecht.

Carlsson, B., Jacobsson, S., 1997. In search of useful public policies: key lessons and issues for policy makers. In: Carlsson, B. (Ed.), Technological Systems and Industrial Dynamics. Kluwer Academic Publishers, Boston, London and Dordrecht, pp. 299-315.

Carlsson, B., Stankiewicz, R., 1991. On the nature, function and composition of technological systems. Evol. Econ. 1 (2), 93-118.

Carlsson, B., Jacobsson, S., Holmén, M., Rickne, A., 2002. Innovation systems: analytical and methodological issues. Res. Policy 31 (2), 233-245.

Cetindamar, D., Laage-Hellmann, J., 2002. Micro-level analysis of firms in the biomedical/biotechnology system in Ohio and Sweden. In: Carlsson, B. (Ed.), Technological Systems in the Bio Industries. Kluwer Academic Publishers, Boston, London and Dordrecht, pp. 81-122.

Chaminade, C., Edquist, C., 2010. Rationales for public policy intervention in the innovation process: a systems of innovation approach. In: Kuhlman, S. Shapira, P., Smits, R. (Eds.), The Theory and Practice of Innovation Policy. An International Research Handbook. Edward Elgar Publishers, London.

Comis, R., 2005. The current situation: Erlotinib (Tarceva ${ }^{\circledR)}$ and Gefitinib (Iressa ${ }^{\circledR}$ ) in non-small cell lung cancer. Oncologist 10 (7), 467-470.

Dedehayir, O., Mäkinen, J.S., 2008. Dynamics of reverse salience as technological performance gap: an empirical study of the personal computer technology system. J. Technol. Manag. Innov. 3 (3), 55-66.

Dowsett, M., Hanby, A.M., Laing, R., Walker, R., 2007. HER2 testing in the UK: consensus from a national consultation. J. Clin. Pathol. 60 (6), 685-689.

Durst, S., Poutanen, P., 2013. Success factors of innovation ecosystems - initial insights from a literature review. Co-Create Conference 2013, Helsinki.

Edquist, C., 1997. Systems of innovation approaches - their emergence and characteristics. In: Edquist, C. (Ed.), Systems of Innovation - Technologies, Institutions and Organizations. Pinter, London, p. 35.

Edquist, C., 2005. Systems of innovation: perspectives and challenges. In: Fagerberg, J., Mowery, D.C., Nelson, R.R. (Eds.), The Oxford Handbook of Innovation. Oxford University Press, New York, pp. 181-208.

Ellis, I.O., Dowsett, M., Bartlett, J., Walker, R., Cooke, T., Gullick, W., Gusterson, B. Mallon, E., Lee, P.B., 2000. Recommendations for HER2 testing in the UK. J. Clin. Pathol. 53 (12), 890-892.

Enzing, C., van den Akker-van, Marle E., Detmar, S., et al., 2006. Case studies and cost-benefit analysis of HER2 and TPMT in four EU member states. Part 2 of an ESTO study on pharmacogenetics and pharmacogenomics: state of the art and social and economic impacts. Technical Report EUR 22214 European Commission, Luxembourg.

Farla, J., Markard, J., Raven, R., Coenen, L., 2012. Sustainability transitions in the making: a closer look at actors, strategies and resources. Technol. Forecast. Soc. Chang. 79 (6), 991-998.

Freeman, C., 1987. Technology Policy and Economic Performance: Lessons From Japan. Pinter Publishers, London.

Fridlyand, J., Simon, R.M., Walrath, J.C., Roach, N., Buller, R., et al., 2013. Considerations for the successful co-development of targeted cancer therapies and companion diagnostics. Nat. Rev. Drug Discov. 12, 743-755.

Galbraith, S., 2013. AstraZeneca: advancing the science and medicine of treating cancer. Cancer Control 34-35.

Garud, R., Hardy, C., Maguire, S., 2007. Institutional entrepreneurship as embedded agency: an introduction to the special issue. Organ. Stud. 28 (7), 957-969.

Geels, F.W., 2002. Technological transitions as evolutionary reconfiguration processes: a multi-level perspective and case-study. Res. Policy 31 (8/9), 1257-1274.

Geels, F.W., 2004. From sectoral systems of innovation to socio-technical systems. Insights about dynamics and change from sociology and institutional theory. Res. Policy 33 (6/7), 897-920.
Genentech, 1998. Genentech and Dako Announce Collaboration on HER2 Diagnostic Kit in Breast Cancer (Press Release 2nd March 1998).

GenNews, 2009. DxS to provide a companion diagnostic for AstraZeneca's NSCLC drug. Genetic Engineering \& Biotechnology News 31st July 2009

Hallam, K., 2012. Roche wins U.K. NICE backing for Tarceva in advanced lung cancer. BusinessWeek 9th May 2012.

Hedgecoe, A.M., 2004. The Politics of Personalised Medicine - Pharmacogenetics in the Clinic. Cambridge University Press, Cambridge.

Hekkert, M.P., Suurs, R.A.A., Negro, S.O., Kuhlmann, S., Smits, R.E.H.M., 2007. Functions of innovation systems: a new approach for analysing technological change. Technol. Forecast. Soc. Chang. 74 (4), 413-432.

Hellsmark, H., 2010. Unfolding of the Formative Phase of Gasified Biomass in the European Union: The Role of System Builders in Releasing the Potential of Second-generation Transportation Fuels from Biomass (PhD Thesis). Department of Energy and Environment, Chalmers University of Technology, Göteborg.

Hellsmark, H., Jacobsson, S., 2009. Opportunities for and limits to academics system builders-the case of realizing the potential of gasified biomassinAustria. Energ Policy 37 (12), 5597-5611.

Herper, M., 2009. AstraZeneca's 'miracle pill' returns. Forbes 19th May 2009.

Hughes, T.P., 1987. The evolution of large technological systems. In: Bijker, W., Hughes, T.P., Pinch, T. (Eds.), The Social Construction of Technological Systems. MIT Press, Cambridge, Mass, pp. 51-82.

Islas, J., 1997. Getting round the lock-in in electricity generating systems: the example of the gas turbine. Res. Policy 26 (1), 49-66.

Jacobsson, S., 2008. The emergence and troubled growth of a 'biopower' innovation system in Sweden. Energ Policy 36 (4), 1491-1508.

Jacobsson, S., Bergek, A., 2004. Transforming the energy sector: the evolution of technological systems in renewable energy technology. Ind. Corp. Chang. 13 (5), 815-849.

Kanter, J., 2005. Roche step is positive signal on Herceptin. New York Times 9th December 2005.

Kukk, P., Moors, E., Hekkert, M.P., 2015. Institutional power play - the case of Herceptin. Res. Policy (submitted for publication, under second review).

Lieberman, M.B., Montgomery, D.B., 1988. First-mover advantages. Strateg. Manag. J. 9, 41-58.

Lundvall, B.-Å. (Ed.), 1992. National Systems of Innovation: Towards a Theory of Innovation and Interactive Learning. Pinter Publishers, London.

Markard, J., Truffer, B., 2008a. Actor-oriented analysis of innovation systems: exploring micro-meso level linkages in the case of stationary fuel cells. Tech. Anal. Strat. Manag. 20 (4), 443-464.

Markard, J., Truffer, B., 2008b. Technological innovation systems and the multilevel perspective: towards an integrated framework. Res. Policy 37 (4), 596-615.

Markard, J., Raven, R., Truffer, B., 2012. Sustainability transitions: an emerging field of research and its prospects. Res. Policy 41 (6), 955-967.

Mayor, S., 2005. Primary care trust reverses decision not to fund trastuzumab. Br. Med. J. 331 (7526), 1162.

McKee, S., 2007. Roche welcomes NICE reassessment of Tarceva. PharmaTimes 2nd October 2007.

Mercan, B., Göktaş, D., 2011. Components of innovation ecosystems: a crosscountry study. Int. Res. J. Finance Econ. 76, 102-112.

Miles, D., Wroath, A., 2001. UK expanded access programme (EAP): Herceptin (trastuzumab) treatment for women with HER2 positive metastatic breast cancer (MBC). 7th Nottingham International Breast Cancer Conference. European Journal of Cancer 37(5), p. 3 (Abstracts).

Miller, I., Ashton-Chess, J., Spolders, H., et al., 2011. Market access challenges in the EU for high medical value diagnostic tests. Pers. Med. 8 (2), 137-148.

Moore, J.F., 1993. Predators and prey: a new ecology of competition. Harv. Bus. Rev. 71 (3), 75-86.

Moore, J.F., 1996. The Death of Competition: Leadership and Strategy in the Age of Business Ecosystems. Harper Business, New York.

Musiolik, J., Markard, J., 2011. Creating and shaping innovation systems: formal networks in the innovation system for stationary fuel cells in Germany. Energ Policy 39 (4), 1909-1922.

Musiolik, J., Markard, J., Hekkert, M.P., 2012. Networks and network resources in technological innovation systems: towards a conceptual framework for system building. Technol. Forecast. Soc. Chang. 79 (6), 1032-1048.

Negro, S.O. Hekkert, M.P., Smits, R.E.H.M. 2007. Explaining the failure of the Dutch innovation system for biomass digestion-a functional analysis. Energ Policy 35 (2), 925-938.

NICE, 2002. Guidance on the use of trastuzumab for the treatment of advanced breast cancer. NICE Technology Appraisal Guidance 34. NICE, London.

NICE, 2008. Erlotinib for the treatment of non-small-cell lung cancer. NICE Technology Appraisal Guidance 162. NICE, London.

NICE, 2010. Gefitinib for the first-line treatment of locally advanced or metastatic non-small-cell lung cancer. NICE Technology Appraisal Guidance 192. NICE, London. 
NICE, 2012. Erlotinib for the first-line treatment of locally advanced or metastatic EGFR-TK mutation-positive non-small cell lung cancer. NICE Technology Appraisal Guidance 258. NICE, London.

Nicholson, A., 2013. Era of molecular targeted therapy for lung cancer: the role of pathology Presentation. Expert Practice in Lung Cancer Meeting Barcelona 6th April 2013.

Olleros, F.-J., 1986. Emerging industries and the burnout of pioneers. J. Prod. Innov. Manag. 3 (1), 5-18.

Olsen, D., Jorgensen, J.T., 2014. Companion diagnostics for targeted cancer drugs - clinical and regulatory aspects. Front. Oncol. 4, 1-8.

OPSI, 1999. The National Institute for Clinical Excellence (Establishment and Constitution) Order 1999 (Press Release 2nd February 1999).

Papazisis, K.T., Habeshaw, T., Miles, D.W., et al., 2004. Safety and efficacy of the combination of trastuzumab with docetaxel for HER2-positive women with advanced breast cancer. A review of the existing clinical trials and results of the expanded access programme in the UK. Int. J. Clin. Pract. 58 (6), 581-586.

Peters, S., Adjei, A.A., Gridelli, C., Reck, M., Kerr, K., Felip, E., 2012. Metastatic non-small-cell lung cancer (NSCLC): ESMO clinical practice guidelines for diagnosis, treatment and follow-up. Ann. Oncol. 23 (7), vii56-vii64.

Pharmaceutical Field, 2008. Putting Patients First. Pharmaceutical Field, UK (June 2008).

PMlive, 2011. Healthcare Collaboration Award. PMLive (2011).

Poole, M.S., van de Ven, A.H., Dooley, K., Holmes, M.E., 2000. Organizational Change and Innovation Processes: Theory and Methods for Research. Oxford University Press, New York.

POST, 2012. Personalised Cancer Treatments. The Parliamentary Office of Science and Technology, London (March 2012, nr 406).

Roche, 2005. Tarceva Approved in Europe for Lung Cancer (Press Release 21st September 2005)

Roche, 2006. Tarceva ${ }^{\circledR}$ (erlotinib) NICE STA submission. Achieving Clinical Excellence in the Treatment of Relapsed Non-small Cell lung Cancer (Roche submission to the NICE 23rd May 2006).

Roche, 2011. Roche's Tarceva Receives European Approval for First-line Use in a Genetically Distinct Type of Lung Cancer (Press Release 1st September 2011).

Rosell, R., Moran, T., Queralt, C., Porta, R., Cardenal, F., Camps, C., Majem, M., Lopez-Vivanco, G., Isla, D., Provencio, M., et al., 2009. Screening for epidermal growth factor receptor mutations in lung cancer. N. Engl. J. Med. 361, 958-967.

Rosell, R., Carcereny, E., Gervais, R., Vergnenegre, A., Massuti, B., Felip, E., Palmero, R., Garcia-Gomez, R., Pallares, C., Sanchez, J.M., et al., 2012. Erlotinib versus standard chemotherapy as first-line treatment for European patients with advanced EGFR mutation-positive non-small-cell lung cancer (EURTAC): a multicentre, open-label, randomised phase 3 trial. Lancet Oncol. 13 (3), 239-246.

Rubens, N., Still, K., Huhtamaki, J., Russell, M.G., 2011. A network analysis of investment firms as resource routers in Chinese innovation ecosystem. J. Softw. 6 (9), 1737-1745.

Sandén, B.A., Hillman, K.M., 2011. A framework for analysis of multi-mode interaction among technologies with examples from the history of alternative transport fuels in Sweden. Res. Policy 40 (3), 403-414.

Suurs, R.A.A., 2009. Motors of Sustainable Innovation. Towards a Theory on the Dynamics of Technological Innovation Systems (PhD Thesis). Innovation Studies Group, Utrecht University, Utrecht.

Suurs, R.A.A., Hekkert, M.P., Smits, R.E.H.M., 2009. Understanding the build-up of a technological innovation system around hydrogen and fuel cell technologies. Int. J. Hydrog. Energy 34 (24), 9639-9654.
The Department of Heath, 2012. Ensuring Equitable Access to Complex Molecular Diagnostic Testing for Cancer Patients (Press Release 26th April 2012).

Truffer, B., Markard, J., Binz, C., Jacobsson, S., 2012. Energy innovation systems: structure of an emerging scholarly field and its future research directions. Strategic Research Alliance for Energy Innovation Systems and their Dynamics. Denmark in global competition, Lyngby, DK.

Tuma, R.S., 2005. Trastuzumab trials steal show at ASCO meeting. J. Natl. Cancer Inst. 97 (12), 870-871.

Van Alphen, K., Hekkert, M.P., Turkenburg, W.C., 2010. Accelerating the deployment of carbon capture and storage technologies by strengthening the innovation system. Int. J. Greenhouse Gas Control 4 (2), 396-409.

Van de Ven, A.H., 1990. Methods for studying innovation development in the Minnesota Innovation Research Program. Organ. Sci. 1 (3), 313-335.

Weber, M.K., Rohracher, H., 2012. Legitimizing research, technology and innovation policies for transformative change. Combining insights from innovation systems and multi-level perspective in a comprehensive 'failures' framework. Res. Policy 41 (6), 1037-1047.

Wieczorek, A.J., Hekkert, M.P., 2012. Systemic instruments for systemic innovation problems: a framework for policy makers and innovation scholars. Sci. Public Policy 39 (1), 74-87.

Wilking, N., Jönsson, B., 2005. A Pan-European Comparison Regarding Patient Access to Cancer Drugs. Karolinska Institutet, Stockholm.

Wilking, N., Jönsson, B., Högberg, D., 2009. Comparator Report on Patient Access to Cancer Drugs in Europe. Karolinska Institutet, Stockholm School of Economics, Stockholm.

Wirth, S., Markard, J., 2011. Context matters: how existing sectors and competing technologies affect the prospects of the Swiss Bio-SNG innovation system. Technol. Forecast. Soc. Chang. 78 (4), 635-649.

Zahra, S.A., Nambisan, S., 2012. Entrepreneurship and strategic thinking in business ecosystems. Bus. Horiz. 55 (3), 219-229.

P. Kukk is a doctoral candidate in innovation studies, University of Utrecht.

Prof. Dr. Ellen H.M. Moors is a professor of 'Innovations in Life Sciences' at the Department of Innovation \& Environmental Studies, Utrecht University. She is studying innovation processes in biotechnology and healthcare, focusing on (1) technology dynamics of industrial innovation processes, especially in science based sector (2) user innovations, especially user-producer interactions in emerging technological fields (e.g. functional genomics), (3) sustainable drug innovation and (4) governance arrangements.

Prof. Dr. Marko P. Hekkert is a professor of 'Innovation System Dynamics' at the Department of Innovation \& Environmental Studies, Utrecht University. Most of his studies focus on technological fields that contribute to a more sustainable society like renewable energy technologies. Theoretically he aims to contribute to the innovation systems perspective by improving our knowledge on how emerging innovation systems develop and what type of micro-mechanisms (power, lobby, research, strategy, expectations, resources) determine the dynamics of innovation systems. 